\title{
High bacterial load of indoor air in hospital wards: the case of University of Gondar teaching hospital, Northwest Ethiopia
}

\author{
Zemichael Gizaw*, Mulat Gebrehiwot and Chalachew Yenew
}

\begin{abstract}
Background: The air inhaled by people is abundantly populated with microorganisms which also are called bioaerosols. Bioaerosols is a colloidal suspension, formed by liquid droplets and particles of solid matter in the air, whose components contain or have attached to them viruses, fungal spores and conidia, bacterial endospores, plant pollen and fragments of plant tissues. They account for 5-34 \% of indoor air pollution.

Methods: A cross-sectional study was conducted to assess the bacteriological concentration and to identify specific species of bacteria in the indoor air of Gondar University teaching hospital. Air samples were taken from 14 randomly selected wards. Bacterial measurements were made by passive air sampling technique i.e., the settle plate method. In each ward five Petri dishes were exposed for 30 and $60 \mathrm{~min}$ in the morning and afternoon. Bacteria were collected on nutrient agar and blood agar media. Both quantitative and qualitative analyses were conducted. The quantitative analysis was mainly conducted to determine bacterial load or number of bacteria in the indoor air. Bacterial load was enumerated as colony forming units. Qualitative analysis was conducted to identify specific species of bacteria. For this study we have selected Staphylococcus aureus and Streptococcus which had high public health concern. Mannitol test was used to isolate Staphylococcus aureus, whereas Bacitracin test was conducted to isolate Streptococcus pyogene.

Result: The result of this study indicated that the highest bacterial load which was $1468 \mathrm{CFU} / \mathrm{m}^{3}$ has been recorded at 2:00 PM in Ward C at 60 min exposure time and the lowest bacterial concentration (i.e., $480 \mathrm{CFU} / \mathrm{m}^{3}$ ) was recorded at 8:00 AM in physiotherapy ward. Based on the result bacterial concentration of indoor air of Gondar University teaching hospital was found between 480 and $1468 \mathrm{CFU} / \mathrm{m}^{3}$. The result of one way ANOVA showed that the highest mean bacterial concentration $\left(1271.00 \mathrm{CFU} / \mathrm{m}^{3}\right)$ was found in Medical ward and the least $\left(583.25 \mathrm{CFU} / \mathrm{m}^{3}\right)$ concentration was found in ward $\mathrm{D}$ and the grand total average concentration was $878.43 \mathrm{CFU} / \mathrm{m}^{3}$. Favorable conditions for growth and multiplication of bacteria like temperature $\left(26.5-29.5^{\circ} \mathrm{C}\right)$, humidity $(64.5-85 \%)$, presence of unhygienic attached toilets, poor waste management system and poor ventilation system were observed during the survey. Staphylococcus aureus was identified in 10 wards and Streptococcus pyogenes was isolated in 8 hospital wards.

Conclusions: Compared with different indoor air biological standards, higher concentration of indoor air bacterial load was found in Gondar University teaching hospital. The higher bacterial load may be due to temperature, humidity, presence of unhygienic attached toilets, poor waste management system and poor ventilation system. Therefore, attention must be given to control those environmental factors which favor the growth and multiplication of microbes in indoor environment. In addition, also the ventilation condition, cleanliness of toilets, sweeping methods and waste disposal system of the compound should be improved.
\end{abstract}

Keywords: Indoor air, Bacterial load, Hospital wards, Settling plate, Mannitol test, Bacitracin test

\footnotetext{
* Correspondence: zemichael12@gmail.com

Department of Environmental and Occupational Health and Safety, Institute

of Public Health, College of Medicine and Health Sciences, University of

Gondar, Gondar, Ethiopia
} 


\section{Background}

Exposure to microorganisms suspended in the air of both occupational and residential indoor environments is associated with a wide range of adverse health effects with major public health impacts. The quality of indoor air is one of the most significant factors affecting the health and well being of people who inhale at least $10 \mathrm{~m}^{3}$ of the air every day, and spend between $80-95 \%$ of their lives indoors $[1,2]$.

The air inhaled by people is abundantly populated with microorganisms which are also called bioaerosols. Bioaerosol is a colloidal suspension, formed by liquid droplets and particles of solid matter in the air, whose components contain or have attached to them viruses, fungal spores and conidia, bacterial endospores, plant pollen and fragments of plant tissues. They account for $5-34 \%$ of indoor air pollution [3-5].

In many environments such as hospitals, the presence of bioaerosols can compromise normal activities. Infectious aerosols tend to be extremely small $(<5 \mu \mathrm{m})$ and can, therefore, remain suspended and viable in the air stream over long periods of time, resulting in extremely high risk of airborne infection in confined places. Nosocomial infection is a serious and widespread problem with many of the infections associated with person to person contact with an estimated 1 in 10 patients acquiring an infection during a hospital stay. While many of these infections are associated with person-to-person contact, there is increasing evidence that some infections are transmitted by the airborne route. It has been calculated that the airborne route of transmission may account for as much as $10-20 \%$ of all endemic nosocomial infections $[2,6]$.

Indoor air pollution is among the leading avoidable causes of disease and death. Globally, 4.3 million deaths were attributable to household air pollution in 2012, almost all in low and middle income countries. The South East Asian and Western Pacific regions bear most of the burden with 1.69 and 1.62 million deaths, respectively. Almost 600,000 deaths occur in Africa, 200,000 in the Eastern Mediterranean region, 99,000 in Europe and 81,000 in the Americas. The remaining 19,000 deaths occur in high income countries $[7,8]$. The health burden from indoor air pollution can also be expressed in Disability Adjusted Life Years (DALYs). The WHO [9] reports that 41 million DALYs were lost due to indoor air pollution. Eleven percent of all deaths in low income countries are due to lower respiratory infections which are caused by indoor air pollution [10].

In hospitals, the problem of Staphylococcus aureus and Streptococcus pyogenes is a global public health problem, but it is particularly serious in resource limited countries. The most common skin bacterial infections are caused by Staphylococcus aureus and Streptococcus pyogenes. Staphylococcus aureus and Streptococcus pyogenes are general pathogens found in hospitals which may cause severe invasive infections [11].

For this study, we used settle plates technique to estimate bacterial load in the indoor air of wards. Passive air sampling uses "settle plates", which are standard Petri dishes containing culture media, which are exposed to the air for a given time in order to collect biological particles which "sediment" out and are then incubated. According to some authors, passive sampling provides a valid risk assessment as it measures the harmful part of the airborne population which falls on to a critical surface, such as in the surgical cut or on the instruments in operating theatres [12]. In addition, active air sampling is applicable when the concentration of microorganisms is not very high. However, hence building and environmental conditions of the hospital are very poor; we suspect that there will be very high concentration of microorganisms [13-16].

\section{Methods \\ Aims of the study}

This study was conducted to assess bacteriological concentration of the indoor air of Gondar University teaching hospital. The study was also aimed to identify specific types of bacteria, namely Staphylococcus aureus from Staphylococcus species and Streptococcus pyogenes from Streptococcus species which have high public health significance.

\section{Study design}

Cross-sectional study was conducted to assess the bacteriological concentration and to identify specific species of bacteria in the indoor air of Gondar University teaching hospital.

\section{Sampling procedures}

Air samples were taken from 14 randomly selected wards of the hospital, namely surgery, emergency, orthopedic, general ward, radiology, obstetric, medical ward, psychiatry, optometry, TB ward, ward C, ward D, physiotherapy, and kalaazar wards which provided patient care services at the time of data collection.

Bacterial measurements were made by passive air sampling technique i.e., the settle plate method using $9 \mathrm{~cm}$ diameter Petri dishes. In each ward five Petri dishes were exposed for 30 and $60 \mathrm{~min}$ in the morning and afternoon. The sampling height which approximated to human breathing zone was $1 \mathrm{~m}$ above the floor and at the center of the room. To minimize dilution of air contaminants, openings like doors and windows were closed including the mechanical ventilators during sampling. In addition, the movement of people during sampling was restricted to avoid air disturbance and newly emitted microorganisms. Bacteria were collected on nutrient agar and blood agar 
media. To obtain the appropriate surface density for counting and to determine the load with respect to time of exposure, the sampling times were set at 30 and $60 \mathrm{~min}$ in the morning (at 8:00 AM) and afternoon (2:00 PM).

By this survey building related factors (like sweeping methods of the floor, design, presence of attached toilets, ventilation, temperature and humidity) and compound sanitation (i.e., waste management systems) were assessed.

\section{Air sample analysis}

Both quantitative and qualitative analyses were conducted. The quantitative analysis was mainly conducted to determine bacterial load or number of bacteria in the indoor air. To determine the load, exposed culture medias/ air samples were taken to the laboratory and incubated at $37{ }^{\circ} \mathrm{C}$ for $24 \mathrm{~h}$. After $24 \mathrm{~h}$ incubation period, bacterial load was enumerated as colony forming units (CFU) and $\mathrm{CFU} / \mathrm{m}^{3}$ were determined by the formula $N=\mathbf{5 a}^{*} \mathbf{1 0 ^ { 4 }}(\mathbf{b t})^{-\mathbf{1}}$ [17-19], where $N=$ microbial $\mathrm{CFU} / \mathrm{m}^{3}$ of indoor air; $\mathrm{a}=$ number of colonies per Petri dish; $\mathrm{b}=$ dish surface $\left(\mathrm{cm}^{2}\right)$; and $\mathrm{t}=\mathrm{ex}$ posure time (minutes). Besides, one way ANOVA was also conducted to obtain the mean bacterial concentration of wards.
Qualitative analysis was conducted to identify specific species of bacteria. For this study we have selected Staphylococcus aureus and Streptococcus which had high public health concern. Mannitol test was used to isolate Staphylococcus aureus, and Bacitracin test was conducted to isolate Streptococcus pyogenes.

Staphylococcus aureus was isolated by Mannitol Salt Agar Plate, a selective agar medium which inhibits the growth of most bacteria other than staphylococcus species especially Staphylococcus aureus.

Bacitracin test is sensitivity test used to differentiate the beta- hemolytic Streptococcus. Streptococcus pyogenes (group A streptococci) is bacitracin sensitive species and inhibited by the small amount of bacitracin in the disk. Any zone of inhibition around the disk indicates positive result and no zone of inhibition indicates negative result.

\section{Sample quality}

To secure the quality of the study, aseptic techniques like utilization of safety clothes; sterilization of sampling utensils; cold storage and handling of serialized utensils; proper incubation of samples were applied. Field blanks were also used to check the presence of cross contamination.

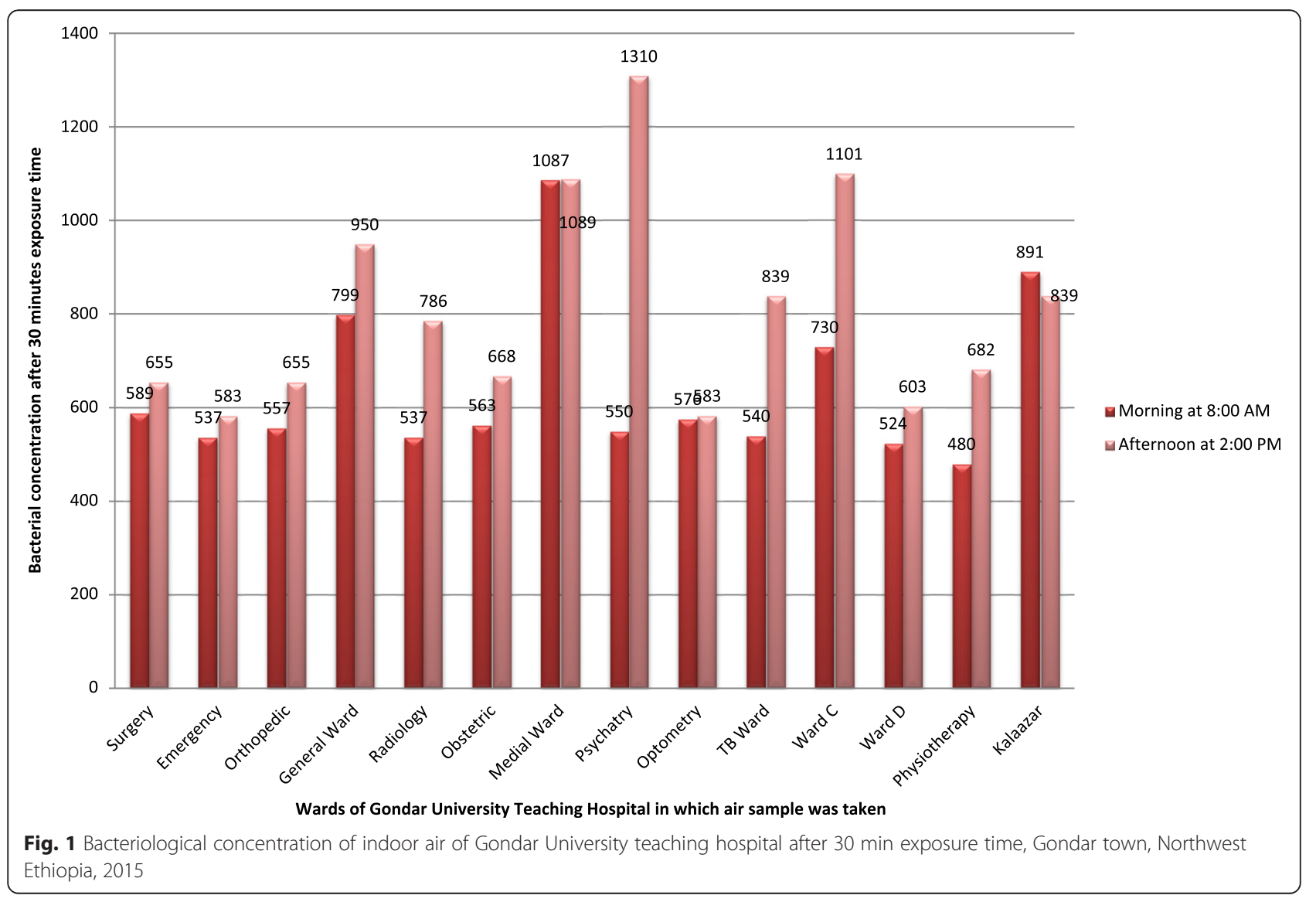




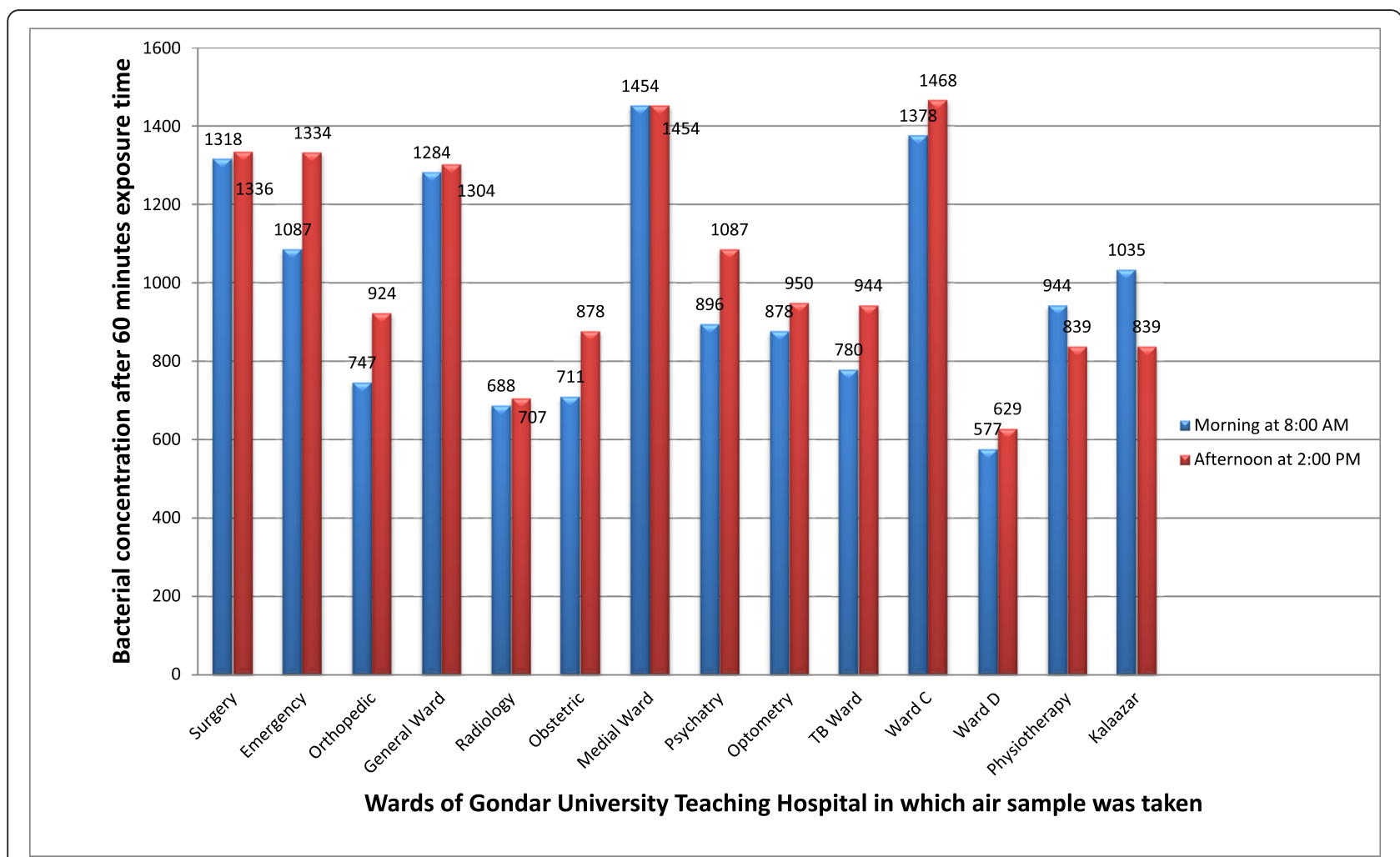

Fig. 2 Bacteriological concentration of indoor air of Gondar University teaching hospital after 60 min exposure time, Gondar town, Northwest Ethiopia, 2015

Table 1 Bacteria isolated from each investigated ward of Gondar University teaching hospital, Gondar town, Northwest Ethiopia, 2015

\begin{tabular}{lll}
\hline Investigated wards & Staphylococcus aureus & Streptococcus pyogenes \\
\hline Surgery & + & + \\
Emergency & + & - \\
Orthopedic & - & + \\
General ward & + & + \\
Radiology & + & - \\
Obstetric & + & - \\
Medical ward & + & - \\
Psychiatry & - & - \\
Optometry & + & - \\
TB ward & + & + \\
Ward C & + & + \\
Ward D & + & + \\
Physiotherapy & - & + \\
Kalazar ward & - & + \\
\hline
\end{tabular}

\section{Results}

\section{Bacterial load}

The result of this study indicated that the highest bacterial load (which was $1468 \mathrm{CFU} / \mathrm{m}^{3}$ ) has been found at 2:00 $\mathrm{PM}$ in Ward $\mathrm{C}$ at $60 \mathrm{~min}$ exposure time and the lowest bacterial concentration (i.e., $480 \mathrm{CFU} / \mathrm{m}^{3}$ ) was recorded at 8:00 $\mathrm{AM}$ in physiotherapy ward at $30 \mathrm{~min}$ exposure time (Figs. 1 and 2).

\section{Specific types of bacteria}

In this study two species of bacteria which have high public health significance, namely Staphylococcus aureus and Streptococcus pyogenes were isolated. As the test result indicated, these two bacteria are found in most of the wards (Table 1).

\section{Building and compound condition}

The result of this survey revealed that wards are constructed in areas prone to contamination. The site was characterized by indiscriminate waste disposal. Unhygienic attached toilets were observed. Microorganisms from these unhygienic toilets may transmit to the wards by people or air current. There were no mechanical ventilations in any of the wards. As a result, buildings are ventilated by the aid of natural ventilation system which may 
Table 2 One way ANOVA results for mean bacterial concentration of wards in Gondar University Teaching Hospital, 2015

\begin{tabular}{|c|c|c|c|c|c|c|}
\hline \multirow[t]{2}{*}{ Wards } & \multirow[t]{2}{*}{ Mean } & \multirow[t]{2}{*}{ Std. error } & \multicolumn{2}{|c|}{$95 \%$ Confidence interval for mean } & \multirow[t]{2}{*}{ Minimum } & \multirow[t]{2}{*}{ Maximum } \\
\hline & & & Lower bound & Upper bound & & \\
\hline Surgery & 974.5000 & 203.99449 & 325.2985 & 1623.7015 & 589.00 & 1336.00 \\
\hline Emergency & 885.2500 & 194.66055 & 265.7533 & 1504.7467 & 537.00 & 1334.00 \\
\hline Orthopedic & 720.7500 & 78.06875 & 472.3004 & 969.1996 & 557.00 & 924.00 \\
\hline General ward & 1084.2500 & 125.02691 & 686.3586 & 1482.1414 & 799.00 & 1304.00 \\
\hline Radiology & 679.5000 & 52.02323 & 513.9389 & 845.0611 & 537.00 & 786.00 \\
\hline Obsetetric & 705.0000 & 65.50954 & 496.5194 & 913.4806 & 563.00 & 878.00 \\
\hline Medical ward & 1271.0000 & 105.65589 & 934.7558 & 1607.2442 & 1087.00 & 1454.00 \\
\hline Psychatry & 960.7500 & 160.94066 & 448.5650 & 1472.9350 & 550.00 & 1310.00 \\
\hline Opthometry & 746.7500 & 97.68433 & 435.8749 & 1057.6251 & 576.00 & 950.00 \\
\hline TB ward & 775.7500 & 85.58853 & 503.3691 & 1048.1309 & 540.00 & 944.00 \\
\hline Ward c & 1169.2500 & 165.93843 & 641.1599 & 1697.3401 & 730.00 & 1468.00 \\
\hline Ward d & 583.2500 & 22.42162 & 511.8944 & 654.6056 & 524.00 & 629.00 \\
\hline Physiotherapy & 736.2500 & 100.96400 & 414.9375 & 1057.5625 & 480.00 & 944.00 \\
\hline Kalazar & 1005.7500 & 93.74556 & 707.4098 & 1304.0902 & 839.00 & 1258.00 \\
\hline Total & 878.4286 & 38.99062 & 800.2896 & 956.5675 & 480.00 & 1468.00 \\
\hline
\end{tabular}

increase the possibility of entrance of pollutants from the unhygienic external environment. Even though wet moping was recommended to reduce aerosols, dry sweeping was being practiced which may increase bio - aerosols in the indoor air. The temperature $\left(26.5-29.5{ }^{\circ} \mathrm{C}\right)$ and humidity $(64.5-85 \%)$ of each ward were at the favorable range for the growth and multiplication of bacteria.

\section{ANOVA test for mean bacterial concentration}

One way ANOVA test was conducted to obtain the mean bacterial concentration of wards as presented below. The highest mean bacterial concentration $\left(1271.00 \mathrm{CFU} / \mathrm{m}^{3}\right)$ was found in Medical ward and the least $\left(583.25 \mathrm{CFU} / \mathrm{m}^{3}\right)$ concentration was found in Ward D. The grand total average concentration was $878.43 \mathrm{CFU} / \mathrm{m}^{3}$ (Table 2).

ANOVA test result was presented to show the mean bacterial concentration difference among different wards. The test showed that there was significant mean bacterial concentration difference among wards (Table 3).

\section{Discussion}

In this study the bacterial concentration of indoor air of Gondar University teaching hospital wards was found in the range between 480 and $1468 \mathrm{CFU} / \mathrm{m}^{3}$. This range of

Table 3 ANOVA test result on mean bacterial concentration difference among different wards

\begin{tabular}{lcccll}
\hline Source of variation & Sum of squares & df & Mean square & F & Sig. \\
\hline Between groups & 2172222.214 & 13 & 167094.016 & 2.796 & 0.006 \\
Within groups & 2510205.500 & 42 & 59766.798 & & \\
Total & 4682427.714 & 55 & & & \\
\hline
\end{tabular}

bacterial load is much lesser than that reported from Jima University specialized hospital in which it was estimated between 2123 and $9733 \mathrm{CFU} / \mathrm{m}^{3}$ [20]. Though there is no uniform international standard available on levels and acceptable maximum bacterial loads in indoor air, the work conducted by a WHO expert group on assessment of health risks of biological agents in indoor environments suggested that total microbial load should not exceed $1000 \mathrm{CFU} / \mathrm{m}^{3}$ [21], whereas other scholars considered that $750 \mathrm{CFU} / \mathrm{m}^{3}$ should be the limit for bacteria $[22,23]$. Airborne microbial concentrations ranging from 4500 to $10,000 \mathrm{CFU} / \mathrm{m}^{3}$ also have been suggested as the upper limit for ubiquitous bacterial aerosols [24]. The sanitary standards of European Commission for non industrial premises consider less than $50 \mathrm{CFU} / \mathrm{m}^{3}$ as 'very low' bacterial load, $50-100 \mathrm{CFU} / \mathrm{m}^{3}$ as 'low', $100-500 \mathrm{CFU} / \mathrm{m}^{3}$ as 'intermediate', $500-2000 \mathrm{CFU} / \mathrm{m}^{3}$ as 'high' and above $2000 \mathrm{CFU} / \mathrm{m}^{3}$ as 'very high' load [25]. According to these standards the bacterial load of Gondar University teaching hospital is considered as 'high'.

This study revealed that there were no mechanical ventilations in any of the wards. Buildings were being ventilated by the aid of natural ventilation system which may increase the possibility of entrance of pollutants from the unhygienic external environment. This might be the reason why bacterial load was higher in different wards as a number of other studies also indicated that insufficient ventilation system contributes to the high microbial loads of the wards [26-30].

In this study, temperature and humidity of the wards also were measured. The temperature $\left(26.5-29.5{ }^{\circ} \mathrm{C}\right)$ and humidity (64.5-85\%) ranges of the wards recorded are 
generally favorable for survival and multiplication of microorganisms. Temperature and humidity range unfavorable for microbial growth is between 20 and $22{ }^{\circ} \mathrm{C}$ and 30-60\%, respectively. This might be the reason for high load of microorganisms in different wards of Gondar University teaching hospital as also suggested by other similar studies [27, 29, 31, 32].

Presence of unhygienic attached toilets and poor waste management system were observed during the survey. These conditions do have certain implications with regard to indoor air quality. Toilets and waste disposal sites should be located at a significant distance away from the hospital wards as they could be a potential source of infection. This study suggests that the higher bacterial load in the wards may be due to the presence of unhygienic attached toilets in the wards and poor waste management system. This explanation is supported by the results of other researches as well [33-35].

\section{Conclusions}

Compared with different indoor air biological standards, higher bacterial concentration of indoor air was found in Gondar University teaching hospital. The higher bacterial load may be due to temperature, humidity, insufficient ventilation, presence of unhygienic attached toilets and poor waste management system. Hence the bacterial load is very high in all wards; attention should be taken for the immunocompromised patients. Attention must be also given to control those environmental factors which favor the growth and multiplication of microbes in indoor environment. In addition, also the ventilation condition of the wards, cleanliness of toilets and waste disposal system should be improved.

\section{Ethics approval}

Ethical clearance was obtained from Institutional Ethical Committee of University of Gondar. Then, official letter from the University of Gondar Research and Community Service Vice President and supportive letter from college of Medicine and Health sciences was written to the respective responsible bodies. Confidentiality of the data was maintained. No identifiers except coding were included in the data collection tools.

\section{Abbreviations}

$\mu \mathrm{m}$ : micrometer; AM: ante meridian; ANOVA: analysis of variance; CFU: colony forming units; $\mathrm{cm}^{2}$ : centimeter square; DALYs: disability adjusted life years; $\mathrm{m}^{3}$ : cubic meter; ${ }^{\circ} \mathrm{C}$ : degree centigrade; PM: post meridian; WHO: World Health Organization.

\section{Competing interest}

The authors declare that they have no competing interests.

\section{Authors' contribution}

All the authors actively participated during conception of the research issue, development of research proposal, sample collection, analysis and interpretation, and writing various parts of the research report. The final manuscript is prepared by Mr. Zemichael Gizaw. All authors read and approved the final manuscript.

\section{Acknowledgment}

First of all, we acknowledge our GOD for being with us and help us in every aspect to accomplish this study. We also extend our grateful thanks to the

Gondar University teaching hospital laboratory managers and technicians.

Received: 16 March 2016 Accepted: 24 April 2016

Published online: 05 July 2016

\section{References}

1. Dacarro C, Picco AM, Grisoli R, Redolfi M. Determination of aerial microbiological contaminations in scholastic sports environment. J Appl Microbiol. 2003;95:904-12.

2. Piotrowska M, Zakowska Z, Gliścińska A, Bogusławska-Kozłowska J. The role of outdoor air on fungal aerosols formation in indoor environment. Łódź: Proceedings of the II International Scientific Conference: Microbial Biodegradation and Biodeterioration of Technical Materials; 2001;113-8.

3. Kalogerakis N, Paschali D, Lekaditis V, Pantidou A, Eleftheriadis K, Lazaridis M. Indoor Air quality - bioaerosol measurements in domestic and office premises. J Aerosol Sci. 2005;36:751-61.

4. Karwowska E. Microbiological air contamination in farming environment. Pol J Environ Stud. 2005:14:445-9.

5. Karbowska-Berent J, Górny RL, Strzelczyk AB, Wlazło A. Airborne and dust borne microorganisms in selected Polish libraries and archives. Build Environ. 2011:46:1872-9.

6. Shiaka GP, Yakubu SE. Comparative analysis of airborne microbial concentrations in the indoor environment of Two selected clinical laboratories. IOSR J Pharm Biol Sci (IOSR-JPBS). 2013;8:4.

7. World Health Organization (WHO). Burden of disease from indoor air pollution for 2012. Availlable at http://www.who.int/phe/health_topics/ outdoorair/databases/HAP_BoD_results_March2014.pdf. Accessed 26 Apr. 2016

8. Flannigan B. Microbial aerosols in buildings: origins, health implications and controls. Łódż: Proceedings of the II International Scientific Conference: Microbial Biodegradation and Biodeterioration of Technical Materials; 2001. p. 11-27.

9. World Health Organization (WHO). Global health observatory database. Geneva: WHO; 2009. Accessed 26 Apr. 2016. Available at http://www.who. int/gho/database/en/. Accessed 26 Apr. 2016.

10. Wardlaw TM, Johansson EW, Hodge M, World Health Organization, UNICEF. Pneumonia: the forgotten killer of children. 2006. Available at http://www. unicef.org/publications/files/Pneumonia_The_Forgotten_Killer_of_Children. pdf. Accessed 26 Apr. 2016.

11. Catalanotti P, Catania MR, Lucido M, Martini S, Gallè F, Ortega De Luna L, et al. T serotyping and genomic profile of erythromycin-resistant or -sensitive Streptococcus pyogenes isolated in Campania Region, Italy. J Chemother. 2005;17(2):131-7. 2005.

12. French MLV, Eitzen HE, Ritter MA, Leland DS. Environmental control of microbial contamination in the operating room. In: Hunt TK, editor. Wound healing and wound infection. New York: Appleton-Century Crofis; 1980. p. 254-61.

13. Pasquarella C, Albertini R, Dall'Aglio P, Saccani E, Sansebastiano GE, Signorelli C. Air microbial sampling: the state of the art.lg. Sanita Pubbl. 2008;64:79-120

14. ISO. Cleanrooms and associated controlled environments-Bio contamination control. Part 1: General principles and methods. Milano: UNl; 2003. 14698-1.

15. Blomquist G. Sampling of biological particles. Analyst. 1994;119:53-6.

16. Center for Disease Control and Prevention (CDC). Guidelines for environmental infection control in health-care facilities. Atlanta: 2003. Available at http:// www.cdc.gov/ncidod/dhqp/gl_environinfection.htm. Accessed 26 Apr. 2016.

17. Omeliansky VL. Manual in microbiology. Moscow: USSR academy of sciences; 1940.

18. Fleischer M, Bober-Gheek B, Bortkiewicza O, Rusiecka-Ziólkowska J. Microbiological control of airborne contamination in hospitals. Indoor Build Environ. 2006;15(1):53-6. 
19. Toivol AM, ALM S, Reponen T, Kolari S, Nevalainen A. Personal exposures and micro environmental concentrations of particles and bioaerosols. J Environ Monit. 2002;4:166.

20. Fekadu S, Getachewu B. Microbiological assessment of indoor air of Teaching hospital wards: a case of Jimma University specialized hospital. Ethiop J Health Sci. 2015;25:2.

21. Nevalainen A, Morawaska L. Biological agents in indoor environments. Assessment of health risks. Work conducted by a WHO Expert Group between 2000 - 2003. WHO, QUT. 2009. Availlable at http://www. buildingforensics.co.uk/uploads/files/buildingforensics.co.uk_996163695.rtf. Accessed 26 Apr. 2016

22. Francisco RAN, Luiz FGS. Guidelines for indoor air quality in offices in Brazil. Proc Healthy Buildings. 2000;4:549-54

23. Cappitelli F, Fermo P, Vecchi R, Pizzalunga A, Valli G, Zanardini E, et al. Chemical-physical and microbiological measurements for indoor air quality assessment at the Ca' Granda historical archive, Milan (Italy). Water Air Soil Pollut. 2009;201:109-20.

24. Nevalainen A. Bacterial aerosols in indoor air, Ph.D. thesis. Kuopio: University of Kuopio; 1989. p. 58, 66, 73 .

25. Commission of European Communities. Biological particles in indoor environments, European Collaborative Action - Indoor Air Quality and its Impact on Man, Report No. 12, CEC, Luxembourg. Availlable at http://www. soer.justice.tas.gov.au/2003/source/94/index.php. Accessed 26 Apr. 2016.

26. Wamedo SA, Ede PN, Chuku A. Interaction between building design and air borne microbial load. Asian J Bio Sci. 2012;5:183-91.

27. Abdelhameed AA, Habeeballah T. Air microbial contamination at the Holy Mosque, Makkah, Saudi Arabia. Curr World Environ. 2013;8(2):179-87.

28. Mirbahar AM, Memon BA. Bacteriological monitoring through air sampling in different location of teaching/civil hospital Sukkur. J App Em Sc. 2005;1(2):13-5.

29. Naruka K, Gaur J, Charaya R. Bioaerosols in healthcare settings: a brief review. Int J Geol Earth Environ Sci. 2014;4(3):59-64.

30. Daisey JM, Angell WJ, Apte MG. Indoor air quality, ventilation and health symptoms in schools: an analysis of existing information. Indoor Air. 2003;13(1):53-64.

31. Tang JW. The effect of environmental parameters on the survival of airborne infectious agents. J R Soc Interface. 2009;6 Suppl 6:S737-46.

32. De Goffau MC, Yang X, van Dij JM, Harmsen HJ. Bacterial pleomorphism and competition in a relative humidity gradient. Environ Microbiol. 2009;11:809-22.

33. Pillai SD, Ricke SC. Bioaerosols from municipal and animal wastes: background and contemporary issues. Can J Microbiol. 2002;48:681-96.

34. Li TC, Ambu S, Mohandas K, Wah MJ, Sulaiman LH, Murgaiyah M. Bacterial constituents of indoor air in a high throughput building in the tropics. Trop Biomed. 2014;31(3):540-56.

35. Gerba CP, Wallis C, Melnick JL. Microbiological hazards of household toilets: droplet production and the fate of residual organisms. Appl Microbiol. 1975; 30(2):229-37.

\section{Submit your next manuscript to BioMed Central and we will help you at every step:}

- We accept pre-submission inquiries

- Our selector tool helps you to find the most relevant journal

- We provide round the clock customer support

- Convenient online submission

- Thorough peer review

- Inclusion in PubMed and all major indexing services

- Maximum visibility for your research

Submit your manuscript at www.biomedcentral.com/submit 